\title{
PENERAPAN TEKNIK KAIL UNTUK MENINGKATKAN PRESTASI BELAJAR PKn PADA SISWA KELAS VII B SMP NEGERI 1 PAYANGAN
}

\author{
Anom Separsa \\ SMP Negeri 1 Payangan \\ E-mail: anomseparsa68@gmail.com
}

\begin{abstract}
ABSTRAK
Penelitian ini bertujuan untuk mengetahui peningkatan prestasi belajar siswa kelas VII B SMP Negeri 1 Payangan dengan penerapan Tehnik KAIL (klarifikasi nilai). Penelitian ini adalah penelitian deskriptif kualitatif dengan rancangan penelitian tindakan Model Kemmis. Subyek penelitian adalah siswa kelas VII B SMP Negeri 1 Payangan, yang berjumlah 33 orang. Data prestasi belajar PKn dikumpulkan dengan tes prestasi belajar berbentuk pilihan ganda dan essay. Analisis data secara kuantitatif dan tehnik analisa data dengan perbandingan hasil prestasi tindakan I dengan hasil prestasi tindakan II. Hasil Penelitian menunjukkan bahwa nilai rata-rata pada siklus I sebesar 69 dan daya serap 69\%, nilai rata-rata pada siklus II sebesar 83 dan daya serap 83\%, peningkatan prestasi belajar sebesar 14 poin dan peningkatan daya serapnya $14 \%$. Ketuntasan belajar pada siklus I sebesar $73 \%$ dan pada siklus II sebesar 91\%, terjadi peningkatan ketuntasan belajar siswa sebesar $18 \%$.
\end{abstract}

Kata Kunci: Prestasi belajar PKn, Teknik Klarifikasi Nilai

\section{ABSTRACT}

This research aims to determine the improvement of learning achievement students of VII B SMP Negeri 1 Payangan with the application of the technique of KAIL (clarification of value).This research is a qualitative descriptive research with draft research action Model Kemmis.The subject of research is class VII B SMP Negeri 1 Payangan, amounting to 33 people.The learning performance Data of PKn is gathered with a study performance test of multiple choice and essay.Quantitative data analysis and data analysis techniques with comparisons of action I achievements with action II performance results. The results showed that the average value in the I cycle was 69 and the absorption rate was 69\%, the average value of the II cycle was 83 and the absorbent power was $83 \%$, an increase in learning performance by 14 points and an increase in its absorption power by $14 \%$.The guidance of learning at cycle I amounted to $73 \%$ and in cycle II by $91 \%$, there has been an increase in student learning by $18 \%$.

Keywords: Learning performance of PKn, value clarification technique

\section{PENDAHULUAN}

Rendahnya kualitas proses dan hasil pendidikan merupakan masalah yang sangat mendasar karena berdampak langsung terhadap rendahnva kualitas sumber daya manusia, yang pada akhirnya menghambat proses pembangunan nasional. Di sisi lain bangsa Indonesia harus mampu melaksanakan pembangunan nasional secara maksmial untuk mengejar ketinggalannya. Khusus dalam bidang pendidikan, masalah rendahnya proses dan hasil pendidikan formal harus diupayakan untuk dicarikan solusi lewat peningkatan kualitas proses pembelajaran, melalui peningkatan kompetensi guru, peningkatan 
sarana teknis pembelajaran seperti penerapan media pembelajaran yang relevan.

Sekolah sebagai salah satu institusi formal memiliki peran yang cukup strategis dan efektif dalam menumbuhkembangkan nilai dan moral kebangsaan. Penanaman dan pengembangan jiwa nasionalisme hendaknya dilakukan semenjak dini, yaitu mulai dari jenjang pendidikan Taman Kanak-Kanak, SMU hingga perguruan tinggi. SMP sebagai salah satu jenjang institusi formal dalam dimensi pendidikan memiliki peran yang sangat strategis dalam mendidik dan mengembangkan potensi warga negara sedini mungkin.

Terjadinya berbagai masalah tersebut semakin menimpa nilai-moral kebangsaan di beberapa daerah yang banyak dilansir oleh media massa dewasa ini diduga salah satunya disebabkan karena teknik dan sistem pembelajaran yang dilakukan oleh para pendidik (guru) selama ini cenderung menempatkan peserta didik sebagai objek pembelajaran dengan pendekatan pembelajaran yang konvensional. Untuk itu, pola pembelajaran yang demikian harus segera diantisipasi dan secara perlahan dirombak, dengan mengembangkan suatu teknik belajar yang mampu memediasi dan mengkondisikan siswa memiliki jiwa-nilai kebersamaan (kesatuan dan persatuan) dalam dimensi latar belakang yang pluralis.

Melalui pembelajaran PKn diharapkan mampu mengkontribusi lahirnya manusia-manusia Indonesia yang mempunyai jiwa dan semangat yang tangguh dalam mendukung dan melaksanakan pembangunan bangsa dan negara sesuai dengan tujuan pendidikan nasional.

Untuk menunjang tercapainya tujuan PKn harus didukung oleh iklim pembelajaran yang kondusif. Iklim pembelajaran yang dikembangkan oleh guru mempunyai pengaruh yang sangat besar terhadap keberhasilan dan kegairahan belajar siswa (Sumantri, 2004), selanjutnya dikatakan pula, bahwa kualitas dan keberhasilan pembelajaran sangat dipengaruhi oleh kemampuan dan ketepatan guru dalam memilih dan menggunakan metode pembelajaran.

Berdasarkan analisis konseptual dan mengkaji kondisi pembelajaran PKn di SMP dewasa ini, ternyata masih banyak guru yang belum memiliki kemampuan dan keterampilan yang memadai dalam memilih dan menggunakan berbagai teknik pembelajaran yang mampu mengembangkan iklim pembelajaran yang kondusif bagi siswa untuk belajar.Bahkan banyak di antara guru yang tidak memiliki kurikulum tertulis yang merupakan pedoman dasar dalam pemilihan teknik pembelajaran. Di samping itu tidak sedikit siswa kesulitan dalam mengikuti pelajaran dikarenakan teknik pembelajaran yang dipilih dan digunakan oleh guru dirasakan kurang tepat (Sumantri, 2004), sehingga proses belajar-mengajar akan berlangsung secara kaku, dan kurang mendukung pengembangan pengetahuan, sikap, moral dan keterampilan siswa.

Pemilihan teknik dan metode pembelajaran yang sesuai dengan tujuan kurikulum dan potensi siswa merupakan kemampuan dan keterampilan dasar yang harus dimiliki oleh seorang guru. Hal ini didasari oleh asumsi bahwa ketepatan guru dalam memilih teknik dan metode pembelajaran akan berpengaruh terhadap 
keberhasilan dan hasil belajar siswa Kondisi proses pembelajaran PKn di lingkungan sekolah dewasa ini masih menekankan pada aspek pengetahuan dan masih sedikit yang mengacu pada pelibatan siswa dalam proses belajar itu sendiri. Faktor lain yaitu pembelajaran PKn yang dilakukan oleh guru-guru pada jenjang sekolah menengah, tidak merangsang siswa untuk terlibat secara aktif dalam proses belajar mengajar. Di samping itu pembelajaran yang dilakukan oleh guru belum mampu menumbuhkan budaya belajar siswa. Hal ini akan berpengaruh secara langsung terhadap perolehan dan hasil belajar siswa, khususnya pada upaya pengembangan dan aktualisasi nilai diri peserta didik.

Kondisi pembelajaran seperti di atas membawa dampak pada rendahnya proses dan hasil belajar yang diperoleh dari siswa. Di samping itu pola dan asumsi guru yang berangkat dari asumsi tesembunyi bahwa pembelajaran PKn adalah proses pemindahan seperangkat fakta, konsep, dan pengalaman mentah dari kepala guru ke kepala siswa secara utuh. Hal ini semakin menjauhkan esensi dan subtansi dari mata pelajaran PKn itu sendiri. Masalah lain yang cukup urgen sehubungan dengan analisis di atas adalah rendahnya kreativitas dan produktivitas siswa, sebagai dampak dari pendekatan konvensional dan pola evaluasi yang bernuansa cognitif orientation. Menyadari begitu strategi misi dan peran yang diemban oleh PKn hendaknya pembelajaran yang di rancang oleh guru mampu mengkondisikan siswa untuk belajar secara optimal dan penuh makna. Jika kondisi ini bisa ditumbuhkembangkan oleh guru, maka akan mendorong siswa untuk mengembangkan potensi diri siswa secara optimal dan komprehensif. Pola pembelajaran yang dirancang semestinya mampu mendorong siswa untuk belajar mandiri dan terampil dalam memecahkan berbagai permasalahan yang dihadapi dalam belajar. Sekolah sebagai lembaga pendidikan memiliki tanggung jawab untuk membentuk generasi muda yang beriman, bertaqwa, berilmu, bermoral, dan memiliki sikap demokratis. Secara khusus mata pelajaran Pendidikan Pancasila dan Kewarganegaraan berusaha untuk menanamkan nilai, norma, dan moral, kepada peserta didik dengan tujuan agar memiliki pengetahuan tentang hukum, politik, moral, dan sikap demokratis. Pembelajaran PKn lebih diarahkan terhadap upaya peningkatan pemahaman, pengahayatan, dan pengamalan nilai-nilai Pancasila dalam kehidupan bermasyarakat, berbangsa, dan bernegara melalui proses pengkajian dan praktik dalam kehidupan sehari-hari dengan cerdas, baik secara rasional maupun secara emosional. Pendidikan Pancasila dan Kewarganegaraan menghadapi tantangan baru dalam upaya menerapkan konsep, nilai, dan cita-cita demokrasi yang sudah berkembang bukan saja sebagai sistem kehidupan bermasyarakat, berbangsa, dan bernegara, tetapi juga sebagai gerakan sosial kesejagatan pergaulan antarbangsa.

$$
\text { Mata pelajaran PKn juga }
$$
mengembangkan berbagai kemampuan dasar warga negara seperti berpikir kritis, mengambil keputusan, memegang teguh aturan yang adil, menghormati hak orang lain, menjalankan kewajiban, bertanggung jawab atas ucapan dan perbuatannya, beriman dan bertaqwa sesuai dengan agamanya, memiliki komitmen terhadap keputusan bersama, mengemukakan 
pikiran secara lisan dan tertulis, berargumentasi, memimpin orang lain, berorganisasi, dan berpartisipasi dalam kehidupan bermasyarakat. Oleh karena itu, sumber belajar tidak hanya terpaku pada buku pelajaran tetapi lebih diperluas lagi dengan memanfaatkan berbagai sumber belajar seperti media masa dan media elektronika serta menyikapi lingkungan masyarakat lokal, nasional, dan global.

Banyak faktor yang berinteraksi dan menyebabkan rendahnya kualitas proses dan produk dari pembelajaran. Khusus pada pembelajaran PKn, pemilihan dan pengembangan pendekatan pembelajaran oleh guru menjadi salah satu kunci dari kualitas proses dan produk pembelajaran yang dilakukannya. Pencapaian kondisi ideal sebagaimana paparan di atas ternyata masih jauh dari realitas di lapangan. Indikator dari hal itu dapat dilihat dari beberapa temuan penelitian sebelumnya.

Salah satu alternatif yang dipandang mampu mengeliminir abrasi moral dan nilai-nilai kebangsaan di kalangan generasi muda dalam konteks pendidikan formal dan meningkatkan hasil belajar siswa dalam pembelajaran PKn di tengah-tengah kehidupan masyarakat global adalah melalui fasilitasi iklim pembelajaran yang memungkinkan siswa untuk mengembangkan potensi dirinya secara optimal sambil melatih keterampilan berpikir dan sosialnya selama berlangsungnya pembelajaran. Salah satu pendekatan pembelajaran yang dipandang mampu mengakomodasi hal itu adalah teknik KAIL(klarifikasi nilai). Berangkat dari kajian empiris dan konseptual tentang permasalahan pembelajaran PKn sebagaimana yang digambarkan di atas, maka penelitian ini akan difokuskan pada penerapan pendekatan pembelajaran PKn yang mampu menjembatani berbagai ketimpangan tersebut.

Penerapan teknik KAIL (klarifikasi nilai) dalam konteks pembelajaran PKn tidak bisa dilepaskan dengan dimensi atau aspek pembelajaran lainnya, seperti entry behavior siswa maupun prior knowledge siswa. Tetapi pada konteks penelitian ini, focus masalah akan diarahkan pada penerapan teknik KAIL (klarifikasi nilai) untuk meningkatkan prestasi belajar PKn, khususnya pembelajaran PKn pada jenjang SMP.

Berdasarkan uraian di atas, dapat disimpulkan bahwa penerapan teknik KAIL (klarifikasi nilai) dapat meningkatkan prestasi belajar PKn. Untuk itu, peneliti mengangkat masalah ini melalui suatu penelitian yang berjudul "Penerapan Teknik KAIL (Klarifikasi Nilai) Untuk Meningkatkan Prestasi Belajar PKn Pada Siswa Kelas VII B SMP Negeri 1 Payangan.

\section{METODE PENELITIAN}

Jenis penelitian ini adalah penelitian deskriptif kualitatif dengan rancangan penelitian tindakan model Kemmis, yang terdiri dari beberapa tahapan yang meliputi perencanaan tindakan, pelaksanaan tindakan, observasi tindakan, dan refleksi tindakan.

Lokasi penelitian tidakan ini dilakukan di SMP Negeri 1 Payangan. Pemilihan kelas VII B yang kelasnya berjumlah 33 orang,dengan perincian lakilaki: 17 orang dan perempuan: 16 orang sebagai subyek penelitian dengan dasar pertimbangan bahwa kelas ini paling sering mengalami permasalahan karena memiliki kemampuan lebih rendah keimbang kelas VII yang lainnya. Data 
pada penelitian ini dikumpulkan dengan metode pengumpulan data yang disesuaikan dengan tuntunan data dari rumusan permasalahan. Berkaitan dengan permasalahan pada penelitian ini maka data yang diperlukan yakni data prestasi belajar PKn. Data prestasi belajar PKn dikumpulkan dengan tes prestasi belajar.

Data yang sudah dikumpulkan dilakukan analisis data secara kuantitatif. dan tehnik analisa data dengan mempergunakan perbandingan antara hasil prestasi tindakan I dengan hasil prestasi tindakan II, yang meliputi: Nilai rata-rata kelas,Tingkat daya serap, dan Tingkat ketuntasan belajar kelas. Untuk ketuntasan belajar baik secara individu maupun klasikal di katakan tuntas jika telah mencapai skor minimal $73 \%$. Nilai prestasi diperoleh dari selisih antara tindakan II (XTK) dengan tindakan I (XTP).Yang mana nilai prestasi dapat dijadikan indicator telah terjadi peningkatan prestasi belajar dalam pembelajaran tersebut.

\section{HASIL PENELITIAN DAN PEMBAHASAN}

Deskripsi data tindakan I dan tindakan II dikelompokan untuk menganalisis penerapan tehnik KAIL (klarifikasi nilai) untuk meningkatkan prestasi belajar PKn pada siswa kelas VII B SMPN 1 Payangan. Hasil belajar siswa pada tidakan I dan tindakan II,dapat dilihat pada Tabel 03 berikut.

Tabel 01 : Hasil belajar siswa pada tindakan I dan tindakan II

\begin{tabular}{ccccc}
\hline NO & ANALISIS NILAI & SIKLUS I & SIKLUS II & PENINGKATAN \\
\hline 1 & Rata-Rata & 69 & 83 & 14 \\
\hline 2 & Daya Serap & $69 \%$ & $83 \%$ & $14 \%$ \\
\hline 3 & Ketuntasan & $73 \%$ & $91 \%$ & $18 \%$ \\
\hline \multirow{2}{*}{ Berdasarkan analisis di peroleh } & $\begin{array}{l}\text { dalam } \\
\text { berbangsa dan bernegara. }\end{array}$
\end{tabular}
gambaran bahwa bahwa nilai rata-rata pada siklus I sebesar 69 dan daya serap $69 \%$, Nilai rata-rata siklus II 83 dan daya serap $83 \%$. Peningkatan yang terjadi sebesar 14 poin dan peningkatan daya serapnya $14 \%$. Ketuntasan belajar pada siklus I $73 \%$ dan siklus II 91\%. Terjadi peningkatan ketuntasan belajar siswa sebesar $18 \%$. Dengan memperhatikan hasil penelitian diatas, peneliti berpendapat bahwa salah satu cara meningkatkan prestasi belajar siswa dalam pembelajaran PKn dengan menerapkan Tehnik KAIL (klarifikasi nilai) merupakan cara yang paling efektif untuk memahami, menghayati dan mengamalkan materi PKn

\section{SIMPULAN DAN SARAN}

Berdasarkan hasil yang diperoleh selama pelaksanaan tindakan kelas dengan menggunakan Tehnik KAIL (klarifikasi nilai) sebagai upaya meningkatkan prestasi belajar siswa dalam pembelajaran PKn, yang dilanjutkan dengan analisa data dan refleksi terhadap pelaksanaan tindakan dapat ditarik simpulan bahwa pembelajaran dengan menggunakan Tehnik KAIL (klarifikasi nilai) dapat meningkatkan prestasi belajar siswa dalam pembelajaran PKn kelas VII B SMP Negeri 1 Payangan. 
Berdasarkan temuan dan hasil analisa terhadap penggunaan Tehnik KAIL (klarifikasi nilai) khususnya dalam pembelajaran PKn dapat ditawarkan sejumlah saran kepada:

1. Guru, khususnya guru PKn, temuan penelitian ini hendaknya dapat dijadikan salah satu acuan dalam melakukan inovasi dan memperkaya strategi pembelajaran PKn sehingga mampu mengemban misinya dalam mencapai tujuan pendidikan nasional.

2. Kepada guru jangan mudah terlena dengan menggunakan satu model pembelajaran sehingga menimbulkan kejenuhan siswa dalam mengikuti pelajaran dan untuk menciptakan proses belajar mengajar yang kondusif dan kolaboratif, maka harus diupayakan penggunaan model yang pariatif serta menggunakan media belajar yang kreatif sehingga dapat membangkitkan aktivitas siswa dalam mengikuti pelajaran.

3. Ibu Kepala Sekolah agar memberikan izin kepada para guru untuk mengikuti dan mempresentasikan apa yang dihasilkan lewat karya ilmiah para guru, sehingga merasa terpacu untuk meningkatkan kompetensinya demi perbaikan proses dan produk lembaga pendidikan.

4. Kepada semua komponen yang terkait agar turut memberikan bantuan serta dorongan kepada guru agar mampu meningkatkan kualitas dirinya demi kepentingan bersama.

\section{DAFTAR PUSTAKA}

Arnyana, I. B. P. (2007). Strategi Belajar Mengajar. Singaraja: Universitas Pendidikan Ganesha.

Dantes, (2012). Metode Penelitian. Yogyakarta: Andi Yogyakarta.
Direktorat Jenderal Pendidikan Tinggi Departemen Pendidikan Nasional. 2007. Kapita Selekta Pembelajaran. Jakarta: Kementerian Pendidikan Nasional RI.

Lasmawan, W.(2004). Pengembangan model pembelajaran IPS sekolah dasar melalui penerapan model STM (Laporan Penelitian). Singaraja: Lembaga Penelitian Undiksha.

Sugiono, (2012). Metode Penelitian Kuantitatif Kualitatif dan $R \& D$. Bandung Alfabeta.

Sukardi, (2010). Evaluasi Pendidikan. Jakarta: PT. Bumi Aksara.

Sumantri, E. (2004). Peningkatan Mutu Pendidikan Sekolah Dasar: Model Penerapan Wawasan, Karakteristik Teori dan Metodologi. (makalah). Disajikan pada Pekan Seminar Mutu Pendidikan di LP IKIP Bandung.

Suwarma.(2011). Epistimologi Pendidikan Ilmu Pengetahuan Sosial. Bandung: Gelar Pustaka Mandiri.

Yuli, R. (2013). Implementasi Teknik Klarifikasi Nilai Berbantuan Foklor dalam Pembentukan Karakter Ke Indonesiaan Siswa Kelas $V$ Pada Pembelajaran PKn di SD Negeri 03 Pontianak Selatan Kalimantan Barat Tesis (tidak diterbitkan). Program Pasca Sarjana UNDIKSHA.

Winarno. (2011). Dinamika Peradaban Global \& Pengaruhnya Bagi Negara Bangsa. Solo: FKIP UNS. 